\title{
INTERFERÊNCIA ENTRE A OCUPAÇÃO URBANA E A DINÂMICA NATURAL NO LITORAL SUL DO PARANÁ
}

\author{
Oduvaldo Bessa Junior*
}

\author{
TESE DE DOUTORADO - Programa de Pós-Graduação em Geologia - UFPR \\ DATA DE DEFESA: 23 jun. 2003
}

Este trabalho tem como objetivo o estudo dos conflitos entre a dinâmica natural das praias da região sul costeira do Paraná e as intervenções humanas sobre elas. As praias estudadas foram os balneários Flamingo e Riviera, Central de Matinhos, Brava de Caiobá, Mansa, Prainha, Caieiras, Guaratuba e Brejatuba. A meta deste trabalho foi a classificação das praias em setores de vulnerabilidade ambiental, que se basearam na mobilidade de cada praia e nos riscos criados a partir da intervenção humana. A mobilidade das praias foi obtida a partir de interpretação de fotografias aéreas de diversos anos, onde foram traçadas as linhas de costa para determinar as taxas de variação da linha de costa. A determinação dos riscos foi baseada no mapeamento das invasões urbanas sobre as faces de praia e no balanço sedimentar das praias obtido a partir dos perfis praiais. Os dados mapeados foram obtidos a partir do geoprocessamento, que auxiliou na construção de um banco de dados georreferenciados e em operações de sobreposição de temas mapeados, como as variações de linha de costa e os riscos de intervenção. As taxas de variação de linha de costa indicaram alta mobilidade para todas as praias estudadas no período de 1999 a 2001. Os resultados do balanço sedimentar também indicaram praias instáveis, com momentos de estabilidade e outros com processos de intensa erosão ou deposição. As causas da estabilidade e instabilidade dessas praias foram associadas a fenômenos interanuais El Niño e La Niña. A determinação dos setores de vulnerabilidade baseou-se em metodologia da Unesco (2000), que permitiu classificar as praias estudadas em setores de vulnerabilidade muito baixa a muito alta. Na Praia Central de Matinhos e na porção nordeste da Prainha ocorreram setores com vulnerabilidade muito alta. Em todas as praias estudadas ocorreram setores com alta vulnerabilidade, sendo que a invasão urbana sobre a face de praia teve influência decisiva na causa do conflito e conseqüente classificação destes setores. Com exceção das praias dos balneários Flamingo e Riviera, da Praia Central e da Prainha, em todas as outras praias ocorreram setores de média vulnerabilidade. Estes podem apresentar alta mobilidade de praia ou intervenção urbana próximo às linhas de costa, mas não ocorre interseção destas variáveis, tal como nos setores de vulnerabilidade alta ou muito alta. Na vulnerabilidade baixa a mobilidade da praia é baixa e a intervenção urbana é praticamente inexistente, enquanto que a vulnerabilidade muito baixa está relacionada às zonas rochosas. Para os setores de vulnerabilidade muito alta (Praia Central de Matinhos e Prainha) recomendou-se um programa de recuperação das praias, para a efetiva resolução dos problemas ambientais. Para os setores de alta vulnerabilidade recomendou-se uma avaliação individualizada de cada setor e um programa de monitoramento de perfis praiais. 